\title{
Density-dependent condition of juvenile penaeid shrimps in seagrass-dominated aquatic vegetation beds located at different distance from a tidal inlet
}

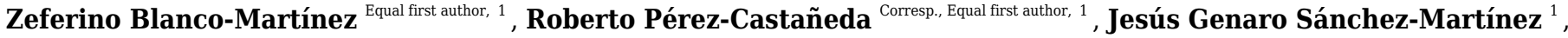 \\ Flaviano Benavides-González ${ }^{1}$, Jaime Luis Rábago-Castro ${ }^{1}$, María de la Luz Vázquez-Sauceda ${ }^{1}$, Lorena Garrido- \\ Olvera $^{2}$ \\ ${ }_{2}^{1}$ Facultad de Medicina Veterinaria y Zootecnia, Universidad Autónoma de Tamaulipas, Victoria, Tamaulipas, Mexico \\ 2 Instituto de Ecología Aplicada, Universidad Autónoma de Tamaulipas, Victoria, Tamaulipas, Mexico \\ Corresponding Author: Roberto Pérez-Castañeda \\ Email address: roperez@docentes.uat.edu.mx
}

Seagrasses are critical habitats for the recruitment and growth of juvenile penaeid shrimps within estuaries and coastal lagoons. The location of a seagrass bed within the lagoon can determine the value of a particular bed for shrimp populations. Consequently, differences in the abundance of shrimp can be found in seagrasses depending on their location. As shrimp density increases, density-dependent effects on biological parameters are more likely to occur. However, knowledge about density-dependent processes on shrimp populations in nursery habitats remains limited. The present investigation was undertaken to examine the effects of population density on shrimp condition in two selected seagrass beds, located at different distance from a tidal inlet, one $25 \mathrm{~km}$ away (distant) and the other $1 \mathrm{~km}$ away (nearby), in a subtropical coastal lagoon. The study was based on monthly samplings during one year in Laguna Madre (Mexico), performing a total of 36 shrimp trawls ( $100 \mathrm{~m}^{2}$ each one) within each seagrass bed ( $n=3$ trawls per bed per month for 12 months). Shrimp density was related to the proximity to the tidal inlet was (higher density was consistently observed in the nearby seagrass bed), which in turn, adversely affected the condition of both species studied (Penaeus aztecus and $P$. duorarum). In this regard, the present study provides the first evidence of density-dependent effects on shrimp condition inhabiting a nursery habitat. Both shrimp species exhibited a negative relationship between condition and shrimp density. However, this pattern differed depending on the proximity to the tidal inlet, suggesting that shrimp populations inhabiting the nearby seagrass bed are exposed to density-dependent effects on condition; whereas, such effects were not detected in the distant seagrass bed. Shrimp density within the distant seagrass bed was probably below carrying capacity, which is suggested by the better shrimp condition observed in that area of the lagoon. Intra and interspecific 
competition for food items is surmised to occur, predominantly within seagrass beds near the tidal inlet. However, this hypothesis needs to be tested in future studies. 
2 Density-dependent condition of juvenile penaeid

3 shrimps in seagrass-dominated aquatic vegetation

4 beds located at different distance from a tidal inlet

5

6

7 Zeferino Blanco-Martínez ${ }^{1}$, Roberto Pérez-Castañeda ${ }^{1}$, Jesús Genaro Sánchez-Martínez ${ }^{1}$,

8 Flaviano Benavides-González ${ }^{1}$, Jaime Luis Rábago-Castro ${ }^{1}$, María de la Luz Vázquez-Sauceda ${ }^{1}$

9 and Lorena Garrido-Olvera ${ }^{2}$

10

11

${ }^{1}$ Facultad de Medicina Veterinaria y Zootecnia, Universidad Autónoma de Tamaulipas, Ciudad

12 Victoria, Tamaulipas, Mexico

13 2 Instituto de Ecología Aplicada, Universidad Autónoma de Tamaulipas, Ciudad Victoria,

14 Tamaulipas, Mexico

15

16 Corresponding author:

17 Roberto Pérez-Castañeda

18 Carretera Victoria-Mante km 5, A.P. 263, Ciudad Victoria, Tamaulipas, 87000, Mexico

19 Email address: roperez@docentes.uat.edu.mx

20

21 Equal first author:

22 Zeferino Blanco-Martínez

23 Roberto Pérez-Castañeda

24 


\section{Abstract}

26 Seagrasses are critical habitats for the recruitment and growth of juvenile penaeid shrimps within

27

28

29

30

31

32

33

34

35

36

37

38

39

40

41

42

43

44

45

46

47

48

49

\section{Introduction}

51 Seagrasses are angiosperms adapted to marine and brackish environments that can be found on

52

53

54

55

56

57

58

59

60

61

62

63

estuaries and coastal lagoons. The location of a seagrass bed within the lagoon can determine the value of a particular bed for shrimp populations. Consequently, differences in the abundance of shrimp can be found in seagrasses depending on their location. As shrimp density increases, density-dependent effects on biological parameters are more likely to occur. However, knowledge about density-dependent processes on shrimp populations in nursery habitats remains limited. The present investigation was undertaken to examine the effects of population density on shrimp condition in two selected seagrass beds, located at different distance from a tidal inlet, one $25 \mathrm{~km}$ away (distant) and the other $1 \mathrm{~km}$ away (nearby), in a subtropical coastal lagoon. The study was based on monthly samplings during one year in Laguna Madre (Mexico), performing a total of 36 shrimp trawls ( $100 \mathrm{~m}^{2}$ each one) within each seagrass bed $(n=3$ trawls per bed per month for 12 months). Shrimp density was related to the proximity to the tidal inlet was (higher density was consistently observed in the nearby seagrass bed), which in turn, adversely affected the condition of both species studied (Penaeus aztecus and P. duorarum). In this regard, the present study provides the first evidence of density-dependent effects on shrimp condition inhabiting a nursery habitat. Both shrimp species exhibited a negative relationship between condition and shrimp density. However, this pattern differed depending on the proximity to the tidal inlet, suggesting that shrimp populations inhabiting the nearby seagrass bed are exposed to density-dependent effects on condition; whereas, such effects were not detected in the distant seagrass bed. Shrimp density within the distant seagrass bed was probably below carrying capacity, which is suggested by the better shrimp condition observed in that area of the lagoon. Intra and interspecific competition for food items is surmised to occur, predominantly within seagrass beds near the tidal inlet. However, this hypothesis needs to be tested in future studies. the bottom of tropical and temperate coastal ecosystems such as bays, estuaries, or coastal lagoons (Short et al., 2007). Seagrass can form extensive beds that provide structural complexity to the coastal habitats. Its coverage and density have a positive influence on the abundance and diversity of different taxonomic groups of macrofauna (McCloskey \& Unsworth, 2015; Junhui et al., 2018; Ruesink et al., 2019). Seagrasses provide refuge and food for the juvenile phase of many species of fish and crustaceans such as penaeid shrimps (Penaeidae family); accordingly, they are recognized as nursery habitats (Jackson et al., 2001).

Submerged aquatic vegetation beds can be constituted by seagrasses, macroalgae, or a mixture of both (Haywood, Vance \& Loneragan, 1995; Githaiga, 2016). Juvenile penaeid shrimps have a marked preference for these habitats, exhibiting generally greater abundance in sites with high density of submerged aquatic vegetation (Loneragan et al., 1998; Pérez-Castañeda et al., 2010). Additionally, higher levels of aquatic vegetation biomass have been directly related to shrimp

PeerJ reviewing PDF | (2020:07:50672:1:1:NEW 29 Oct 2020) 
64 growth rates and inversely related to mortality (Loneragan et al., 2001; Pérez-Castañeda \&

65 Defeo, 2005).

66 Because aquatic vegetation can support a high abundance of shrimp, this could result in

67 competition for resources (e.g., food and shelter) as shrimp density increases, and resources

68 become limited (Begon, Townsend \& Harper, 2006). Evidence of density-dependence in growth

69 and mortality for shrimp in sheltered coastal habitats indicates that the increase in shrimp

70 abundance leads to decreased growth rates and increased mortality (Pérez-Castañeda \& Defeo,

71 2005), which may be due to intra and interspecific competition (Dahl, Edwards \& Patterson,

72 2019).

73 Condition is a biological parameter involving the body weight at a given length; it is related to

74 the availability and consumption of food, reflecting the uptake and allocation of energy (Lloret,

75 Shulman \& Love, 2014). Shrimp condition can be an indicator of the nutritional status of the

76 organisms; however, it may also vary according to the reproductive cycle, where mature shrimp

77 are heavier than immature ones of the same length (Chu et al., 1995). This difference could be

78 due, in part, to the extra weight of the ovaries in mature females, which constitutes up to $13.7 \%$

79 of the total body weight (Peixoto et al., 2003). Shrimps found in coastal lagoons and estuaries are

80 primarily sexually immature juveniles (Dall et al., 1990); therefore, changes in the condition of

81 juvenile shrimps would mainly be associated to their nutritional status, which can be influenced

82 by habitat characteristics.

83 Although there are some studies about the condition in juvenile shrimps (Pérez-Castañeda \&

84 Defeo, 2002; Ochwada-Doyle et al., 2011), density-dependence on shrimp condition has been

85 little explored, particularly in nursery areas. While seagrass beds are key habitats for the

86 recruitment of postlarvae and growth of juvenile shrimp, it has been documented that the

87 location of a seagrass bed within the lagoon can determine the value of a particular bed (Bell,

88 Steffe \& Westoby, 1988). In some coastal lagoons with minimal tidal currents and limited water

89 circulation, like Laguna Madre (Mexico), the distribution of postlarvae within the lagoon could

90 also be limited. In this coastal lagoon, seagrass meadows nearby a tidal inlet, where the

91 postlarvae enter the lagoon, have a greater abundance of shrimp than distant meadows (Blanco-

92 Martínez \& Pérez-Castañeda, 2017). Accordingly, it would be expected that these differences in

93 abundance could result in differences in shrimp condition among seagrass beds. However, this

94 issue has not been assessed. This study aimed to evaluate density-dependence in the condition of

95 two juvenile shrimp species (Penaeus aztecus Ives, 1891 and P. duorarum Burkenroad, 1939) in

96 seagrass-dominated aquatic vegetation beds located at a different distance from a tidal inlet in a

97 coastal lagoon.

98

\section{Materials \& Methods}

100 Sampling and laboratory analysis

101 This study was conducted in the central part of the Laguna Madre (Mexico), which is a $200 \mathrm{~km}$ -

102 long subtropical coastal lagoon located in the Gulf of Mexico $\left(23^{\circ} 50^{\prime}-25^{\circ} 30^{\prime} \mathrm{N}, 97^{\circ} 15^{\prime}-97^{\circ} 45^{\prime} \mathrm{W}\right)$

103 (Fig. 1). The hydrography of Laguna Madre is characterized by a microtidal regime (tidal range 
$104<0.5 \mathrm{~m}$ ) exhibiting limited circulation and exchange with waters from the Gulf of Mexico waters

105 (Britton \& Morton, 1989; Tunnell \& Judd, 2002); therefore, minimal tidal currents within the

106 lagoon are generated.

107 The bottom of the lagoon is characterized by the presence of submerged aquatic vegetation in

108 shallow areas along the coast dominated by submerged seagrasses (Arellano-Méndez et al.,

109 2019), which, due to their subtidal nature, are permanently available for aquatic fauna. The last

110 available mapping of seagrasses in Laguna Madre was performed in the 90s using satellite

111 imagery, which displayed seagrass beds distributed at the north-central portion of the lagoon,

112 mostly along the back of the barrier islands (DUMAC, 1996). The selected seagrass beds for the

113 present study were located at the central portion of the lagoon. They were situated within the

114 band of seagrasses previously mapped. Similarly, larger seagrass meadows have also been

115 recently reported for the central portion of Laguna Madre (Arellano-Méndez et al., 2019);

116 however, there are no data on the distribution of seagrasses at different depth strata in the study

117 area.

118 The location of sampling sites is shown in Fig. 1. They were situated in seagrass beds located at

119 a different distance (distant and nearby) from a tidal inlet. The distant bed was $25 \mathrm{~km}$ from the

120 inlet, while the nearby bed was only $1 \mathrm{~km}$ away. The first seagrass bed was located $1 \mathrm{~km}$ from

121 the tidal inlet and was classified as 'nearby'; the second seagrass bed was located $25 \mathrm{~km}$ from the

122 tidal inlet and served as the 'distant' seagrass bed. The dominant seagrass species in the shrimp

123 nursery habitat were Halodule wrightii (77\% of total seagrass biomass) and Syringodium

124 filiforme (23\% of total seagrass biomass) with the presence of some macroalgal species such as

125 Digenia simplex, Penicillus capitatus, Jania adherens, Laurencia poitei and Champia parvula

126 (Blanco-Martínez \& Pérez-Castañeda, 2017).

127 Monthly shrimp samples were collected at night during an annual cycle (January-December

128 2005) in both seagrass beds (nearby and distant) (Permit from CONAPESCA:

129 DGOPA/05675/060505/.-3869). Data were collected as previously described in Blanco-Martínez

130 \& Pérez-Castañeda (2017). Specifically, field collection and laboratory analysis of shrimp and

131 seagrass samples, as well as measurements of salinity, temperature, and dissolved oxygen in the

132 coastal lagoon, were performed as previously described in the study mentioned above.

133 Measurement of carapace length (CL, mm), weighing (body weight, g), and the taxonomic

134 identification of shrimp were also carried out as described therein. Individuals under $8.0 \mathrm{~mm}$ in

135 carapace length were not identified to species level due to the absence of differentiating

136 morphological characters in those sizes (Pérez-Farfante, 1970).

137 The $2.5 \mathrm{~m}$ long beam trawl (1.3 cm mesh size) utilized for shrimp sampling had a $2 \mathrm{~m}$ wide and

$1380.6 \mathrm{~m}$ high rigid mouth. The sampling gear was hand-hauled parallel to the water's edge

139 (between 1 and $1.5 \mathrm{~m}$ depth approximately), covering a swept area of $100 \mathrm{~m}^{2}$ per tow. Three

140 replicate samples per seagrass bed were taken each month.

141

142 Data analysis 
143 For each seagrass bed, a combined length-frequency distribution (grouped by $1 \mathrm{~mm} \mathrm{CL}$ ), was

144 constructed for all shrimp sampled in order to depict the overall size structure of shrimp by

145 seagrass bed. The monthly mean abundance of shrimp (total and by species) was also plotted for

146 both sites.

147 Carapace length-weight (CL-W) relationships for each shrimp species (P. aztecus and $P$.

148 duorarum) were determined in each seagrass bed. Weight comparison at a given length was

149 utilized as a condition indicator under the assumption that heavier individuals of a given length

150 are in better condition, as considered in previous studies (García-Berthou \& Moreno-Amich,

151 1993; Meretsky et al., 2000). In this regard, an analysis of covariance (ANCOVA) was run on

152 differences in weight at a given length (as an indicator of condition in shrimp) between seagrass

153 beds, with $\log \mathrm{W}$ as the dependent variable and $\log \mathrm{CL}$ as the covariate (Pérez-Castañeda \&

154 Defeo, 2002; Ochwada-Doyle et al., 2011). Data fulfilled the linearity assumption between log

$155 \mathrm{CL}$ and $\log \mathrm{W}$. The homogeneity of slopes (parallelism test) of the fitted linear functions

156 between seagrass beds was also met, allowing the ANCOVA to be carried out. Subsequently, the

157 predicted mean weights for a covariate value of $\mathrm{CL}=11.0 \mathrm{~mm}$ (corresponding to the average

158 size) were obtained from the ANCOVA to illustrate differences in shrimp condition between

159 seagrass beds for each species.

160 Additionally, length-weight relationships were obtained by species ( $P$. aztecus and $P$. duorarum)

161 fitting the power function $W=a C L^{b}$ for each month and seagrass bed. Afterward, fitted models

162 were utilized to estimate the predicted weight at a given length as an indicator of shrimp

163 condition (in this case weight at $\mathrm{CL}=11 \mathrm{~mm}$ ). Finally, monthly shrimp condition was plotted

164 against the monthly mean abundance of total shrimp, fitting a linear function to identify density-

165 dependence in shrimp condition by seagrass bed. It is worth noting that this analysis was

166 performed with data from the months when shrimp were most abundant, in order to guarantee a

167 better representation of length/weight data sets for fitting the aforementioned power function. In

168 this regard, the months included in the analysis were January-April and November-December.

169 Data for $P$. duorarum from November-December in the distant seagrass bed were excluded

170 because of low abundance.

171

\section{Results}

173 Within the lagoon, salinity ranged from 31 to 45 , temperature from 16.6 to $30.2^{\circ} \mathrm{C}$, dissolved

174 oxygen from 2.4 to $6.3 \mathrm{mg} / \mathrm{L}$, seagrass biomass from 10.7 to $1300.7 \mathrm{~g} / \mathrm{m}^{2}$, macroalgal biomass

175 from 5.6 to $457.1 \mathrm{~g} / \mathrm{m}^{2}$ and the total seagrass biomass from 47.5 to $1338.3 \mathrm{~g} / \mathrm{m}^{2}$. Significantly

176 higher mean salinity $(40.6 \pm 4.5)$ and macroalgal biomass $\left(184.6 \pm 127.4 \mathrm{~g} / \mathrm{m}^{2}\right)$ were registered at

177 the distant seagrass bed. The temperature, dissolved oxygen, seagrass biomass, and the total

178 seagrass biomass were slightly higher at the nearby seagrass bed. However, no significant

179 differences were detected in comparison to the distant bed (Table 1, Supplemental information

180 1).

181 Overall, shrimp size ranged from 2.9 to $23.5 \mathrm{~mm} \mathrm{CL}$ in the distant seagrass bed and from 1.5 to

$18226.5 \mathrm{~mm} \mathrm{CL}$ in the nearby seagrass bed. In both vegetation areas, shrimp of 8 to $12 \mathrm{~mm} \mathrm{CL}$ were 
183 the most abundant size classes showing a clear dominance of juveniles (Fig. 2A-B,

184 Supplemental information 2). On the other hand, the abundance of total shrimp and both species

185 were systematically higher in the seagrass bed nearby to the tidal inlet, both annually and in at

186 least ten months throughout the annual cycle (Fig. 2C-H, Supplemental information 2).

187 Shrimp abundance peaked at the beginnin and the end of the year, in the case of total shrimp and

188 P. aztecus. However, P. duorarum abundance only peaked at the beginning of the year (Fig. 2,

189 Supplemental information 2).

190 Length-weight relationships, in logarithmic scale, for both shrimp species from each seagrass

191 bed were successfully fitted by a linear function $(\log \mathrm{W}=\mathrm{a}+\mathrm{b} \log \mathrm{CL})$ with $r^{2}$ values $>0.9$ in

192 all cases (Fig. 3, Supplemental information 3). Both shrimp species showed homogeneity of

193 slopes (parallelism test) among seagrass beds, as indicated by the interaction term between site

194 and $\log \mathrm{CL}$ which was not significant $(p=0.16$ and $p=0.36$ for $P$. aztecus and $P$. duorarum,

195 respectively; Supplementary information 3). The ANCOVA results indicated significant

196 differences $(p<0.001)$ in weight $(\log \mathrm{W})$ at a given length $(\log \mathrm{CL})$ between seagrass beds in

197 both shrimp species (Supplemental information 3).

198 The highest predicted mean weight of shrimps ( $P$. aztecus $=0.785 \mathrm{~g}, P$. duorarum $=0.789 \mathrm{~g})$

199 utilized as an indicator of body condition, were observed at the seagrass bed with lowest shrimp

200 density (total abundance $=43.72$ ind. $\left./ 100 \mathrm{~m}^{2}\right)$. In contrast, the lowest predicted mean weights $(P$.

201 aztecus $=0.751 \mathrm{~g}, P$. duorarum $=0.759 \mathrm{~g}$ ) were found at the seagrass bed with highest shrimp

202 density (total abundance $=105.61$ ind. $/ 100 \mathrm{~m}^{2}$; Fig. 4, Supplemental information 3) indicating

203 that shrimp condition decreased as total shrimp abundance increased.

204 Moreover, when analyzing the data separately by seagrass bed, and merging results from both

205 shrimp species, a negative trend between condition and shrimp abundance was exclusively

206 detected for shrimp inhabiting the aquatic vegetation bed near the tidal inlet (Fig. 5,

207 Supplemental information 4).

208 Although there were significant differences in salinity and biomass of macroalgae between

209 distant and nearby seagrass beds, these variables were not correlated with shrimp abundance and

210 condition (supplemental information 4).

211

\section{Discussion}

213 Although the size range of shrimp was relatively similar in the distant and nearby seagrass beds,

214 the abundance of shrimp was higher in the seagrass area close to the tidal inlet. This pattern was

215 observed practically all year round, suggesting a possible relationship between shrimp abundance

216 and the proximity to the inlet. The microtidal regime in Laguna Madre generates minimal tidal

217 currents and limited water circulation. This condition might limit the distribution of postlarvae

218 within the lagoon as the distance from the source of postlarvae (tidal inlet) increases. This pattern

219 is consistent with what Bell, Steffe \& Westoby (1988) pointed out for recently settled decapods

220 of ocean-spawned species; they hypothesized that the abundance of such species is influenced by

221 their location within the estuary. It has been surmised that the proximity to the tidal inlet could

222 influence the value of seagrass habitats for shrimp recruitment and abundance within the lagoon 
223 (Blanco-Martínez \& Pérez-Castañeda, 2017); however, further studies should be carried out to

224 validate this hypothesis.

225 Because no recently settled postlarvae or very small juvenile shrimp as indicators of recruitment

226 were sampled, no differences in shrimp recruitment was determined between the two seagrass

227 beds. Our study was focused on mid-aged resident juveniles in both subtidal seagrass beds.

228 According to the life cycle of penaeids, shrimp in our study (mostly 6 to $15 \mathrm{~mm}$ CL; Fig. 2A-B)

229 were recruited as postlarvae, approximately at 1-2 mm CL. Afterward, they were probably

230 exposed to predation and competition for several weeks and possible redistribution to

231 microhabitats within the seagrass bed before being sampled as part of this study.

232 The brown shrimp, P. aztecus, has also been reported in intertidal salt marsh vegetation from

233 another subtropical coastal habitat (size range: $10-83 \mathrm{~mm}$ TL or 2-19 $\mathrm{mm}$ CL approximately)

234 (Minello et al., 1989); however, in Laguna Madre salt marsh vegetation is scarce, and therefore,

235 seagrass is the primary habitat with vegetation for penaeid shrimps in this lagoon.

236 The present study provides the first evidence of density-dependent effects on shrimp condition

237 from different seagrass beds vis-à-vis their proximity to a tidal inlet (the site for the entry of

238 postlarvae into the lagoon). The proximity to the tidal inlet was related to the density of shrimp

239 (higher density was consistently observed in the nearby seagrass bed), which in turn, was

240 negatively related to the body condition.

241 Shrimp species ( $P$. aztecus and $P$. duorarum) in Laguna Madre were subject to density-

242 dependent effects on body condition, as indicted by the negative relationship between predicted

243 mean weight and shrimp abundance, coinciding with that reported for $P$. duorarum in another

244 coastal lagoon (Pérez-Castañeda \& Defeo, 2002); however, this pattern differed according to the

245 proximity to the tidal inlet, since such negative influence of density on shrimp condition was

246 detected in the nearby seagrass bed but not in the distant bed (Fig. 5). This finding suggests, that

247 shrimp populations inhabiting the nearby seagrass bed are exposed to density-dependent effects

248 on the condition, while on the contrary, such effects are not present in shrimp populations from

249 the distant bed. The determining factor for the detection of density-dependent effects on the

250 condition between the two seagrass areas was the contrasting difference in shrimp abundance.

251 As the condition was density-dependent, growth could also be negatively affected by shrimp

252 density, particularly in the nearby seagrass bed. Although density-dependent growth has been

253 demonstrated for juvenile shrimp in seagrass habitats through field samplings (Pérez-Castañeda

$254 \&$ Defeo, 2005) and experiments (Loneragan et al., 2001), it has not been assessed whether such

255 density-dependent relationship could be related to distance to the source of postlarvae.

256 Unfortunately, in the present study, it was not possible to carry out the identification and tracking

257 of cohorts over time to estimate shrimp growth, as performed by other authors, because more

258 frequent sampling would have been necessary due to the fast growth of juvenile shrimps before

259 migrating to the sea (Haywood \& Staples, 1993; O'Brien, 1994). Therefore, future studies on the

260 possible effect of density on shrimp growth at different distances from the tidal inlet would be

261 necessary. 
262 Density-dependent effects may be the result of high depletion rates of food sources caused by 263 increments in shrimp density resulting in intra and interspecific competition, as observed in other 264 marine invertebrates (Gaymer, Himmelman \& Johnson, 2002). In this regard, the two closely 265 related shrimp species ( $P$. aztecus and $P$. duorarum) analyzed in the study area (Laguna Madre) 266 represent congeneric and sympatric species that co-occur in seagrass beds, exploiting the same 267 resources (space and food). Thus, both penaeid species may be exposed to intra and interspecific competition, especially as shrimp density increases within the seagrass habitat.

269 The body condition of postlarval and juvenile shrimp may be indicative of their health status.

270 This biological parameter may even affect their ability to escape from predators, as suggested for

271 Penaeus plebejus in Australian coastal lakes, probably resulting in higher mortality for shrimp

272 with a lower condition, i.e., poorer health (Ochwada-Doyle et al., 2011).

273 According to the above, a better body condition of shrimp in the distant seagrass bed in Laguna

274 Madre could imply an advantage for the survival and persistence of shrimp populations within 275 that bed and its possible contribution to the offshore adult's replenishment population. However, 276 the possible effects of body condition on predation should be evaluated.

277 Although from the site representative point of view, our research was limited (only two sampling 278 beds), it was representative in time (three samples per bed per month for 12 months), observing 279 that differences in shrimp condition between seagrass beds were consistent over the study.

280 Higher data dispersion in the nearby bed could be due to greater shrimp patchiness during the months with peak abundance. However, It would be necessary to evaluate possible differences in

282 shrimp patchiness between seagrass beds in the future, based on a higher number of trawls per bed to differentiate between dispersion due to possible patchiness or low representativeness of

284 the sample size.

285 Shrimp size classes represented in our study inhabiting the seagrass habitats are representative of the interrelation of growth, mortality, and migration, and whose future survival will likely

287

288 contribute to the offshore adult population. Although shrimp from the seagrass bed near the tidal

289 inlet had a lower condition, exhibiting density-dependent effects, they were much more abundant and located closer to the adult habitat; i.e., the marine habitat. Therefore, the differential contribution of both seagrass beds (distant and nearby to the tidal inlet) to the adults population

291 should be determined evaluating possible differences in shrimp population dynamics between 292 both beds, including the migration of juveniles to adult habitats (Beck et al., 2001). However, 293 such factors have not yet been quantified.

294

\section{Conclusions}

296 Density-dependent effects on body condition were detected in juvenile penaeid shrimps inhabiting seagrass-dominated aquatic vegetation beds. Data indicated that the proximity to the 298 tidal inlet (site where the postlarvae enter the lagoon) was positively related with the abundance 299 of shrimp, which in turn, was negatively correlated with body condition. This fact was evidenced 300 in both penaeid species ( $P$. aztecus and $P$. duorarum). In this regard, intra and interspecific 
301 competition by food items is hypothesized to occur, predominantly within the seagrass bed near

302 the tidal inlet. However, this hypothesis needs to be tested in future studies.

303

304

305

\section{Acknowledgements}

306

We thank Mr. Emeterio Dueñez Resendiz, from Carboneras village, for his help during biological sampling in Laguna Madre. This work is part of the doctoral thesis of the first author

307 (ZBM) at the Instituto de Ecología Aplicada, Universidad Autónoma de Tamaulipas.

308

309

\section{References}

310

311

312

313

314

315

316

317

318

319

320

321

322

323

324

325

326

327

328

329

330

331

332

333

334

335

336

337

338

339

340

Arellano-Méndez LU, Mora-Olivo A, Zamora-Tovar C, de la Rosa-Manzano E, TorresCastillo JA, Bello-Pineda J. 2019. Structural complexity of tropical seagrasses meadows in a temperate lagoon in the Gulf of Mexico. A landscape ecology approach. Journal of Coastal Conservation 23:969-976 DOI 10.1007/s11852-019-00701-2.

Beck MW, Heck KL Jr, Able KW, Childers DL, Eggleston DB, Gillanders BM, Halpern B, Hays CG, Hoshino K, Minello TJ, Orth RJ, Sheridan PF, Weinstein MP. 2001. The identification, conservation and management of estuarine and marine nurseries for fish and invertebrates. Bioscience 51:633-641 DOI 10.1641/00063568(2001)051[0633:TICAMO]2.0.CO;2.

Begon M, Townsend CR, Harper JL. 2006. Ecology: From individuals to ecosystems. 4th edition. Oxford: Blackwell Publishing.

Bell JD, Steffe AS, Westoby M. 1988. Location of seagrass beds in estuaries: effects on associated fish and decapods. Journal of Experimental Marine Biology and Ecology 122:127146 DOI 10.1016/0022-0981(88)90180-3.

Blanco-Martínez Z, Pérez-Castañeda R. 2017. Does the relative value of submerged aquatic vegetation for penaeid shrimp vary with proximity to a tidal inlet? Marine and Freshwater Research 68:581-591 DOI 10.1071/MF15207.

Britton JC, Morton B. 1989. Shore ecology of the Gulf of Mexico. Austin, TX: University of Texas Press.

Chu KH, Chen QC, Huang LM, Wong CK. 1995. Morphometric analysis of commercially important penaeid shrimps from the Zhujiang estuary, China. Fisheries Research 23:83-93 DOI 10.1016/0165-7836(94)00342-T.

Dahl KA, Edwards MA, Patterson WFIII. 2019. Density-dependent condition and growth of invasive lionfish in the northern Gulf of Mexico. Marine Ecology Progress Series 623:145159 DOI 10.3354/meps13028.

Dall W, Hill BJ, Rothlisberg PC, Sharples DJ. 1990. The biology of the Penaeidae. In: Blaxter JHS, Southward AJ, eds. Advances in Marine Biology Vol. 27. London: Academic Press, 1489.

DUMAC. 1996. Vegetación acuática de la Laguna Madre de Tamaulipas (pastos marinos): Informe final de proyecto. Ducks Unlimited de México, A.C. and Instituto de Ecologia y Alimentos de la Universidad Autónoma de Tamaulipas. Monterrey, Nuevo León.

Peer) reviewing PDF | (2020:07:50672:1:1:NEW 29 Oct 2020) 
341 García-Berthou E, Moreno-Amich R. 1993. Multivariate analysis of covariance in

342

343

344

345

346

347

348

349

350

351

352

353

354

355

356

357

358

359

360

361

362

363

364

365

366

367

368

369

370

371

372

373

374

375

376

377

378

morphometric studies of the reproductive cycle. Canadian Journal of Fisheries and Aquatic Sciences 50:1394-1399 DOI 10.1139/193-159.

Gaymer CF, Himmelman JH, Johnson LE. 2002. Effect of intra- and interspecific interactions on the feeding behavior of two subtidal sea stars. Marine Ecology Progress Series 232:149162 DOI $10.3354 /$ meps 232149 .

Githaiga MN, Gilpin L, Kairo JG, Huxham M. 2016. Biomass and productivity of seagrasses in Africa. Botanica Marina 59:173-186 DOI 10.1515/bot-2015-0075.

Haywood MDE, Staples DJ. 1993. Field estimates of growth and mortality of juvenile banana prawns (Penaeus merguiensis). Marine Biology 116:407-416 DOI 10.1007/BF00350057.

Haywood MDE, Vance DJ, Loneragan NR. 1995. Seagrass and algal beds as nursery habitats for tiger prawns (Penaeus semisulcatus and P. esculentus) in a tropical Australian estuary. Marine Biology 122:213-223 DOI 10.1007/BF00348934.

Jackson EL, Rowden AA, Attrill MJ, Bossey SJ, Jones MB. 2001. The importance of seagrass beds as a habitat for fishery species. In: Gibson RN, Barnes M, Atkinson RJA, eds.

Oceanography and Marine Biology. An Annual Review Vol 39. New York: Taylor \& Francis, 269-303.

Junhui L, Yaqin H, Ucu Yanu A, Heshan L Muhammad Husni A, Jianjun W, Xuebao H, Jianfeng M, Kun L, Shuyi Z. 2018. An ecological survey of the abundance and diversity of benthic macrofauna in Indonesian multispecific seagrass beds. Acta Oceanologica Sinica 37:82-89 DOI 10.1007/s13131-018-1181-9.

Lloret J, Shulman G, Love RM. 2014. Condition and health indicators of exploited marine fishes. Chichester: Wiley-Blackwell.

Loneragan NR, Haywood MDE, Heales DS, Kenyon RA, Pendrey RP, Vance DJ. 2001. Estimating the influence of prawn stocking density and seagrass type on the growth of juvenile tiger prawns (Penaeus semisulcatus): results from field experiments in small enclosures. Marine Biology 139:343-354 DOI 10.1007/S002270100572.

Loneragan NR, Kenyon RA, Staples DJ, Poiner IR, Conacher CA. 1998. The influence of seagrass type on the distribution and abundance of postlarval and juvenile tiger prawns (Penaeus esculentus and P. semisulcatus) in the western Gulf of Carpentaria, Australia. Journal of Experimental Marine Biology and Ecology 228:175-195 DOI 10.1016/S00220981(98)00029-X.

McCloskey RM, Unsworth RKF. 2015. Decreasing seagrass density negatively influences associated fauna. PeerJ 3:e1053 DOI 10.7717/peerj.1053.

Meretsky VJ, Valdez RA, Douglas ME, Brouder MJ, Gorman OT, Marsh PC. 2000. Spatiotemporal variations in length-weight relationships of endangered humpback chub: implications for conservation and management. Transactions of the American Fisheries Society 129:419-428 DOI 10.1577/1548-8659(2000)129<0419:SVILWR>2.0.CO;2.

PeerJ reviewing PDF | (2020:07:50672:1:1:NEW 29 Oct 2020) 
379

380

381

382

383

384

385

386

387

388

389

390

391

392

393

394

395

396

397

398

399

400

401

402

403

404

405

406

407

408

409

410

411

412

413

414

Minello TJ, Zimmerman RJ, Martinez EX. 1989. Mortality of young brown shrimp Penaeus aztecus in estuarine nurseries. Transactions of the American Fisheries Society 118:693-708 DOI 10.1577/1548-8659(1989)118<0693:MOYBSP $>2.3 . C O ; 2$.

O'Brien CJ. 1994. Population dynamics of juvenile tiger prawns Penaeus esculentus in south Queensland, Australia. Marine Ecology Progress Series 104:247-256.

Ochwada-Doyle F, Gray CA, Loneragan NR, Taylor MD, Suthers IM. 2011. Spatial and temporal variability in the condition of postlarval and juvenile Penaeus plebejus sampled from a population subjected to pilot releases. Aquaculture Environment Interactions 2:15-25 DOI 10.3354/aei00026.

Peixoto S, Cavalli RO, D'Incao F, Milach A, Wasielesky W. 2003. Ovarian maturation of wild Farfantepenaeus paulensis in relation to histological and visual changes. Aquaculture Research 34:1255-1260 DOI 10.1046/j.1365-2109.2003.00933.x.

Pérez-Castañeda R, Blanco-Martínez Z, Sánchez-Martínez JG, Rábago-Castro JL, Aguirre-Guzmán G, Vázquez-Sauceda ML. 2010. Distribution of Farfantepenaeus aztecus and $F$. duorarum on submerged aquatic vegetation habitats along a subtropical coastal lagoon (Laguna Madre, Mexico). Journal of the Marine Biological Association of the United Kingdom 90:445-452 DOI 10.1017/S0025315409990865.

Pérez-Castañeda R, Defeo O. 2002. Morphometric relationships of penaeid shrimps in a coastal lagoon: spatio-temporal variability and management implications. Estuaries 25:282-287 DOI 10.1007/BF02691315.

Pérez-Castañeda R, Defeo O. 2005. Growth and mortality of transient shrimp populations (Farfantepenaeus spp.) in a coastal lagoon of Mexico: role of the environment and densitydependence. ICES Journal of Marine Science 62:14-24 DOI 10.1016/J.ICESJMS.2004.10.005.

Pérez-Farfante I. 1970. Diagnostic characters of juveniles of the shrimps Penaeus aztecus aztecus, $P$. duorarum duorarum, and P. brasiliensis (Crustacea, Decapoda, Penaeidae). U.S. Fish and Wildlife Service, Special Scientific Report-Fisheries Number 599.

Ruesink JL, Gross C, Pruitt C, Trimble AC, Donoghue C. 2019. Habitat structure influences the seasonality of nekton in seagrass. Marine Biology 166:75 DOI 10.1007/s00227-019-3519$\mathrm{z}$.

Short F, Carruthers T, Dennison W, Waycott M. 2007. Global seagrass distribution and diversity: A bioregional model. Journal of Experimental Marine Biology and Ecology 350:320 DOI 10.1016/j.jembe.2007.06.012.

Tunnel JW Jr, Judd FW. 2002. The Laguna Madre of Texas and Tamaulipas. College Station, TX: Texas A\&M University Press. 


\section{Table $\mathbf{1}$ (on next page)}

Environmental conditions and submerged aquatic vegetation biomass.

Mean $( \pm S D$ ) values of abiotic factors (salinity, temperature and dissolved oxygen) and biomass of seagrass and macroalgae, including total biomass, in two seagrass-dominated aquatic vegetation beds located at different distances (distant and nearby) from a tidal inlet in Laguna Madre (Mexico). Probability values of statistical comparisons (Student's $t$ tests) between beds are included. 


\section{Table 1:}

2 Environmental conditions and submerged aquatic vegetation biomass.

3 Mean $( \pm S D)$ values of abiotic factors (salinity, temperature and dissolved oxygen) and

4 biomass of seagrass and macroalgae, including total biomass, in two seagrass-

5 dominated aquatic vegetation beds located at different distances (distant and nearby)

6 from a tidal inlet in Laguna Madre (Mexico). Probability values of statistical comparisons

7 (Student's $t$ tests) between beds are included.

8

\begin{tabular}{lccc}
\hline & $\begin{array}{c}\text { Distant } \\
\text { seagrass bed }\end{array}$ & $\begin{array}{c}\text { Nearby } \\
\text { seagrass bed }\end{array}$ & $p$-value \\
\hline Salinity & $40.6 \pm 4.5$ & $37.4 \pm 2.6$ & 0.042 \\
Temperature $\left({ }^{\circ} \mathrm{C}\right)$ & $24.9 \pm 5.0$ & $25.3 \pm 4.4$ & 0.847 \\
Dissolved oxygen $(\mathrm{mg} / \mathrm{L})$ & $4.2 \pm 1.1$ & $4.6 \pm 0.9$ & 0.345 \\
Seagrass $\left(\mathrm{g} / \mathrm{m}^{2}\right)$ & $310.8 \pm 259.1$ & $433.1 \pm 330.6$ & 0.324 \\
Macroalgae $\left(\mathrm{g} / \mathrm{m}^{2}\right)$ & $184.6 \pm 127.4$ & $84.7 \pm 103.4$ & 0.047 \\
Total biomass $\left(\mathrm{g} / \mathrm{m}^{2}\right)$ & $495.4 \pm 319.1$ & $517.8 \pm 311.2$ & 0.863 \\
\hline
\end{tabular}

9 


\section{Figure 1}

Study area.

Location of sampling sites in seagrass beds in Laguna Madre (Mexico). The distant (D) and nearby $(\mathrm{N})$ seagrass beds were located at $25 \mathrm{~km}$ and $1 \mathrm{~km}$ away, respectively, from the tidal inlet (Boca de Catán). 


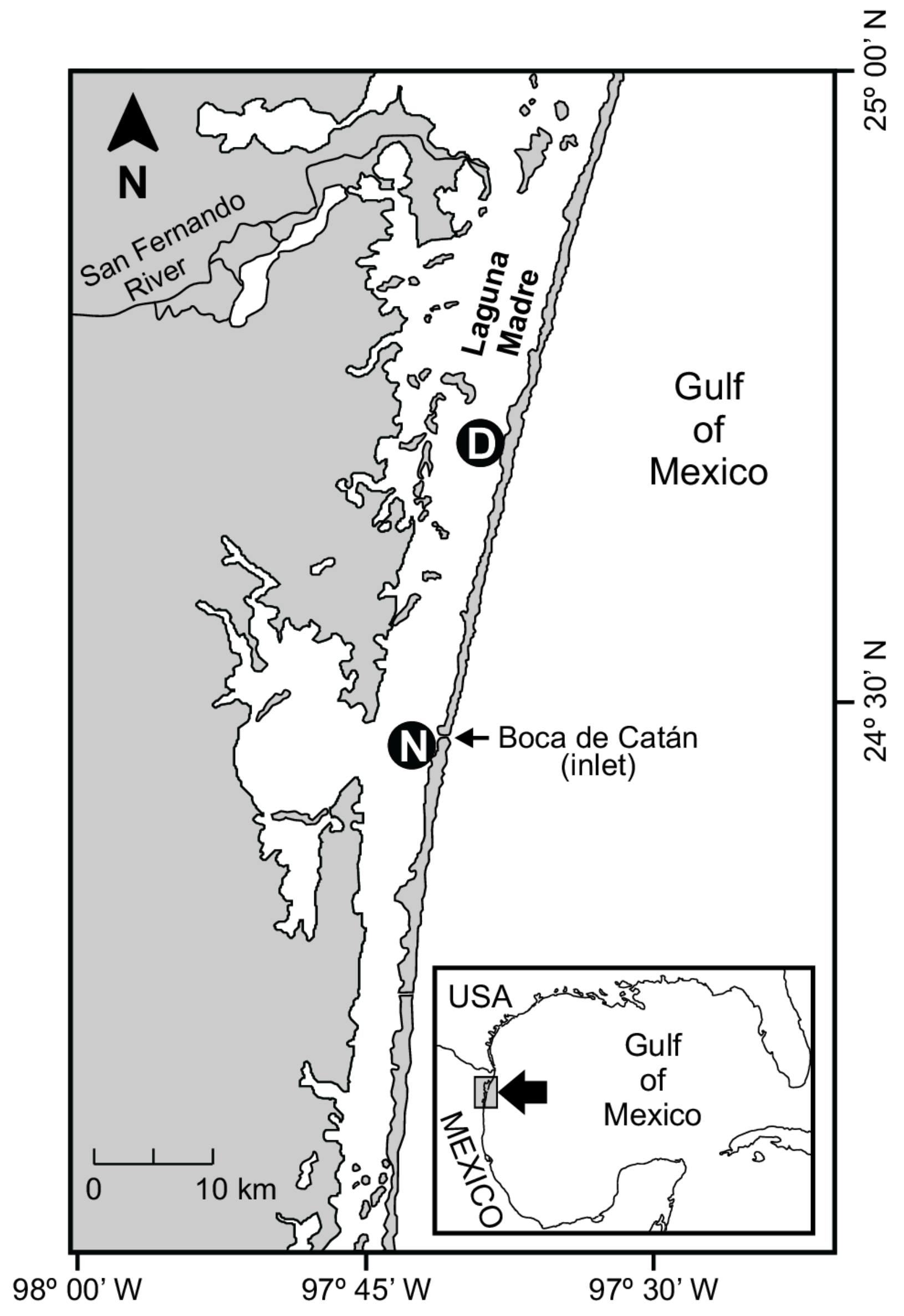


Figure 2

Penaeid shrimps collected in two different seagrass beds in relation to their proximity to a tidal inlet (distant and nearby) in Laguna Madre (Mexico).

(A, B) Length-frequency distributions in carapace length (CL) of all penaeids grouped by 1 $\mathrm{mm} \mathrm{CL}$. Monthly abundance (mean $\pm \mathrm{SD}$ ) of shrimp is displayed as (C, D) total abundance, (E, F) Penaeus aztecus and (G, H) P. duorarum, respectively. 
Distant

seagrass bed
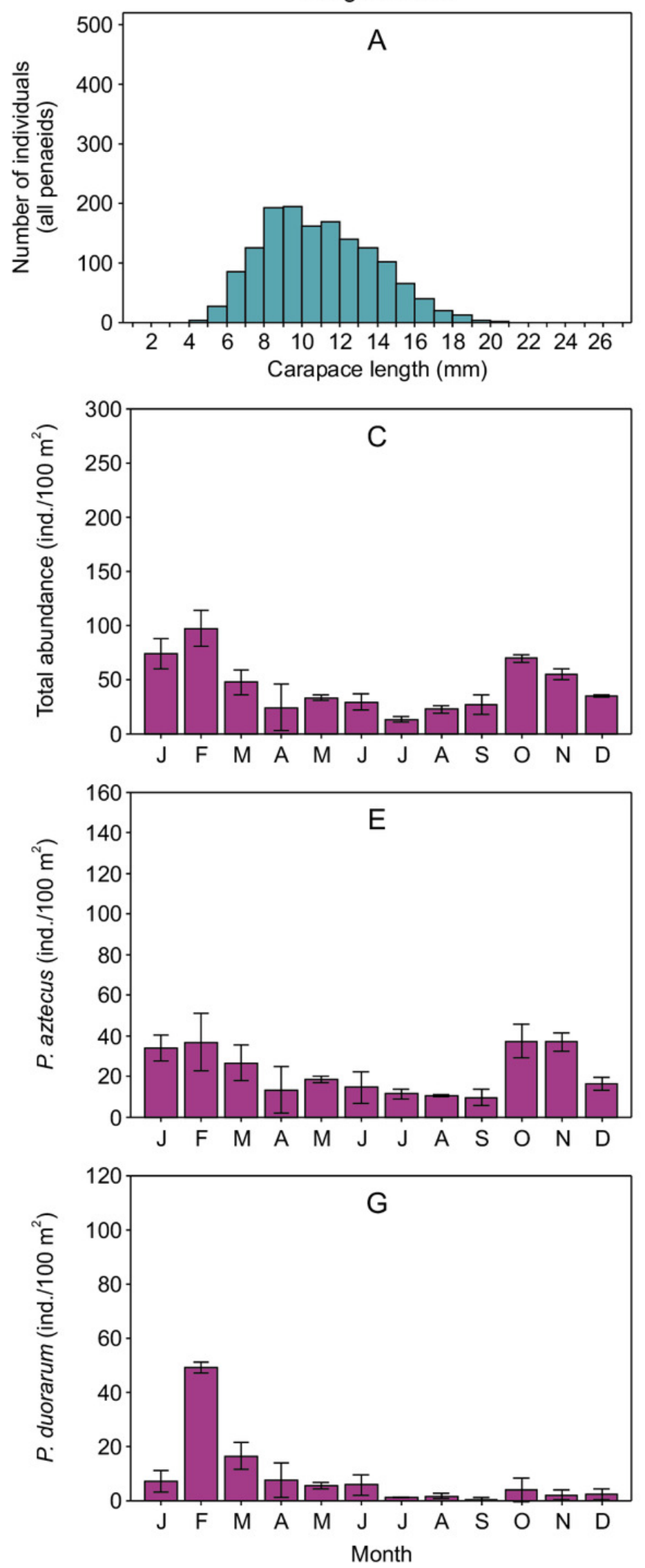

Nearby seagrass bed
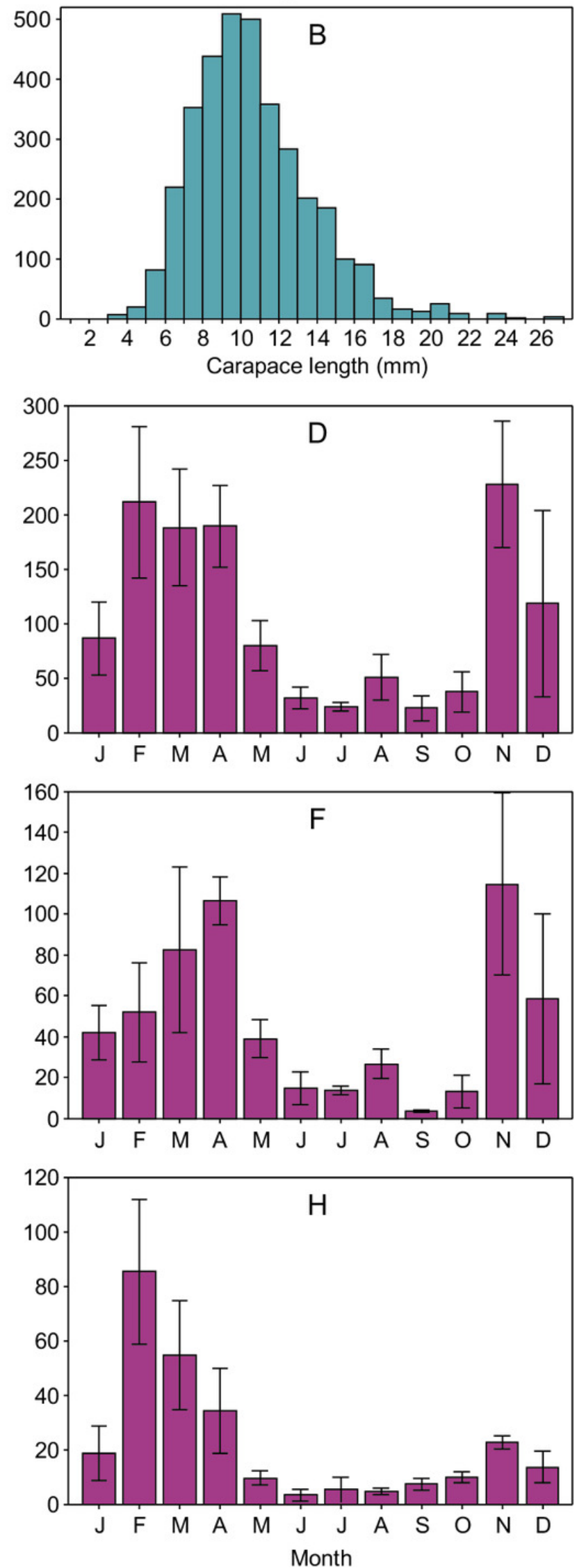
Figure 3

Carapace length-weight relationships (in logarithmic scale) for juvenile Penaeus shrimps from two different seagrass beds, distant and nearby to a tidal inlet, in Laguna Madre.

(A) $P$. aztecus: $r^{2}=0.92, n=685$ in the distant bed, and $r^{2}=0.93, n=1426$ in the nearby bed;

(B) P. duorarum: $r^{2}=0.95, n=258$ in the distant bed, and $r^{2}=0.93, n=686$ in the nearby bed. 

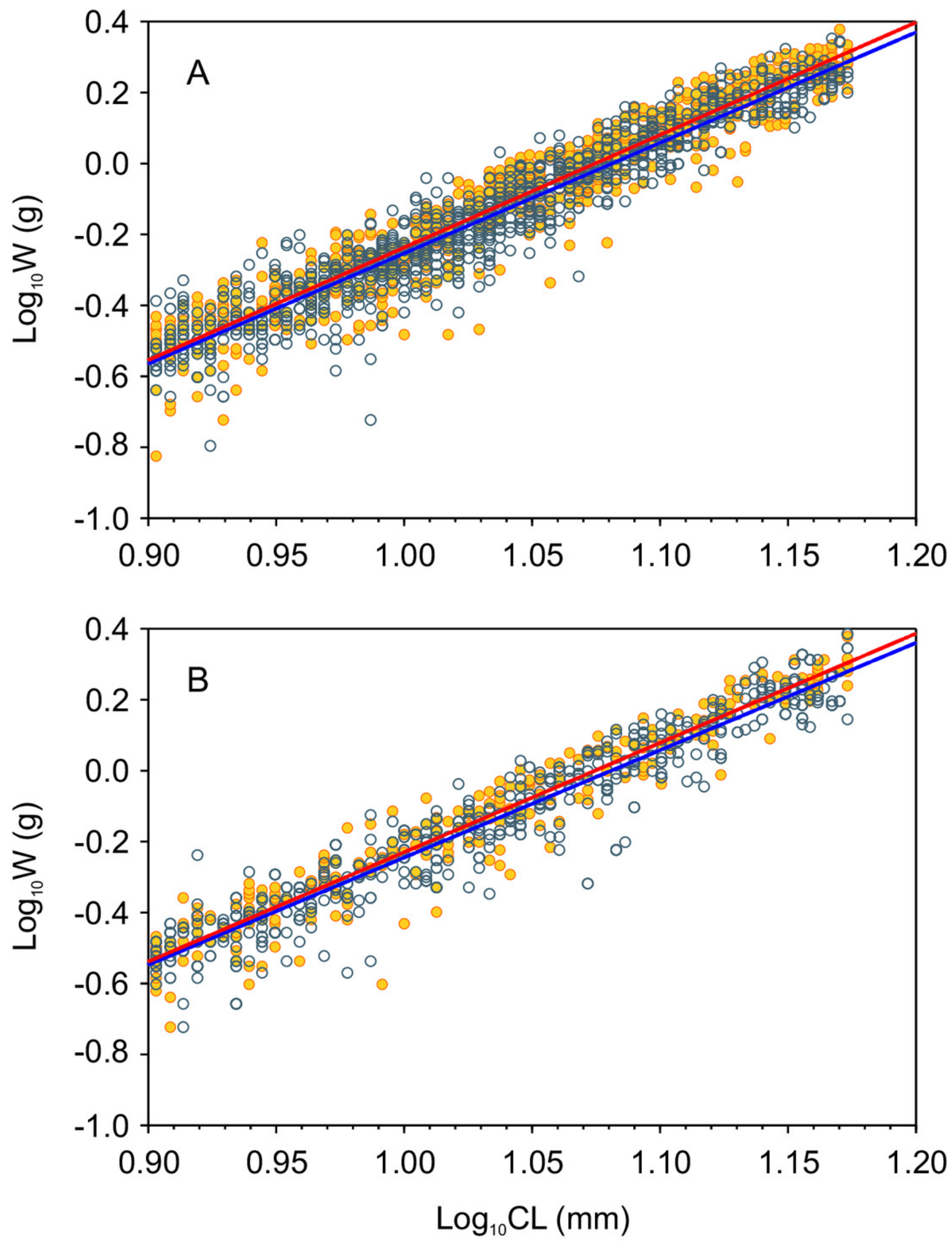

$\ominus$ Distant seagrass bed $\quad$ Nearby seagrass bed 


\section{Figure 4}

Condition and abundance of Penaeus shrimps from two different seagrass beds in relation to their proximity to a tidal inlet (distant and nearby) in a coastal lagoon.

(A) Individual predicted mean weight $( \pm \mathrm{SE}$ ) at a length of $11 \mathrm{~mm} \mathrm{CL}$ as an indicator of condition for $P$. aztecus and (B) P. duorarum. (C) Mean ( \pm SE) total shrimp abundance.

A

P. aztecus

(condition)

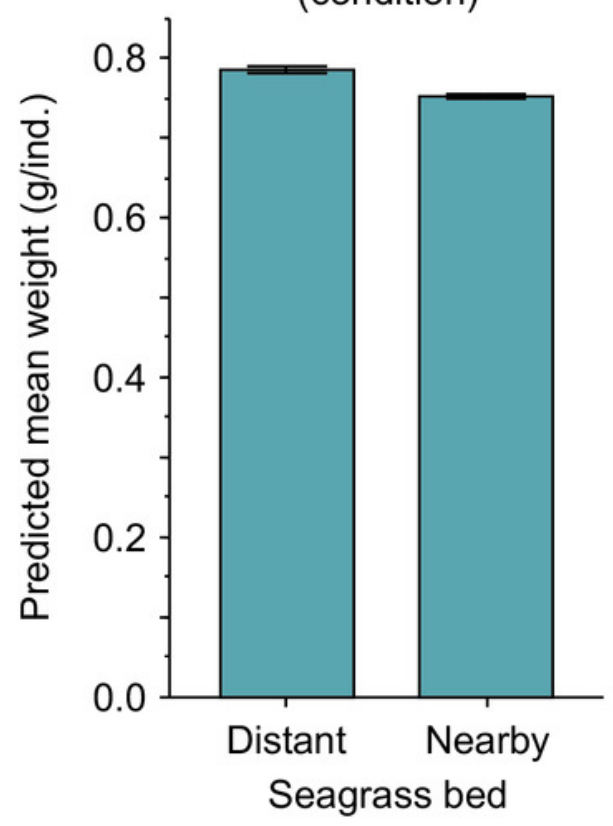

$\mathrm{B}$

P. duorarum

(condition)

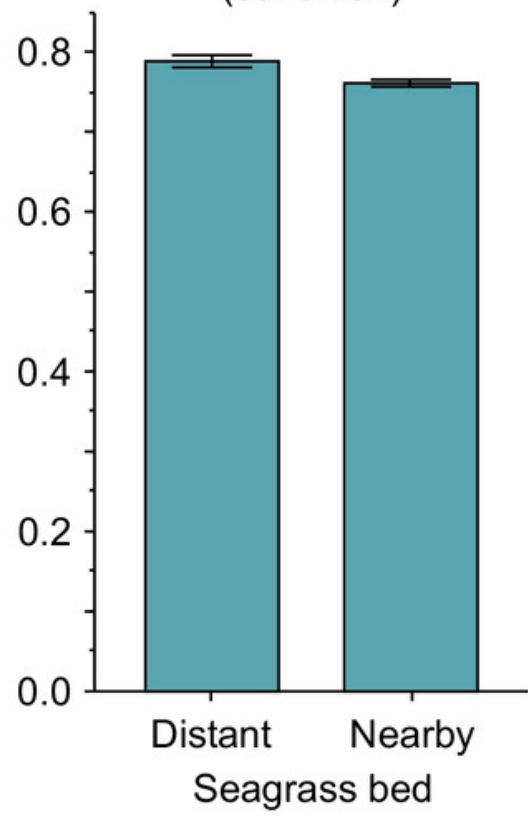

C

Total

abundance

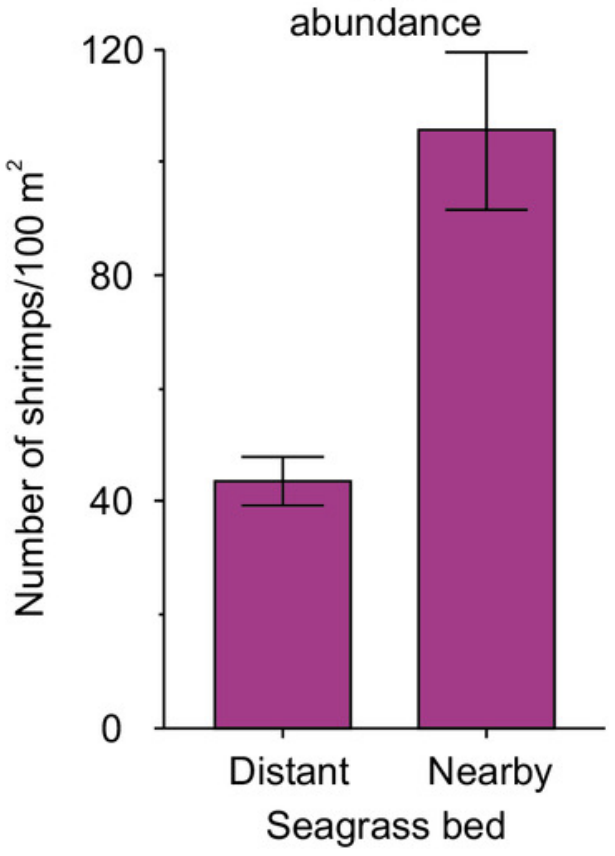




\section{Figure 5}

Relationship between body condition (combined data from Penaeus aztecus and $P$. duorarum) and total shrimp abundance in two seagrass beds, one distant and one near the tidal inlet in a coastal lagoon.

(A) No significant (ns) relationship was detected in the distant bed, whereas (B) a negative linear function between both variables was observed for shrimp in the nearby seagrass bed. Individual predicted mean weight at length of $11 \mathrm{~mm} \mathrm{CL}$ was utilized as an indicator of condition. 

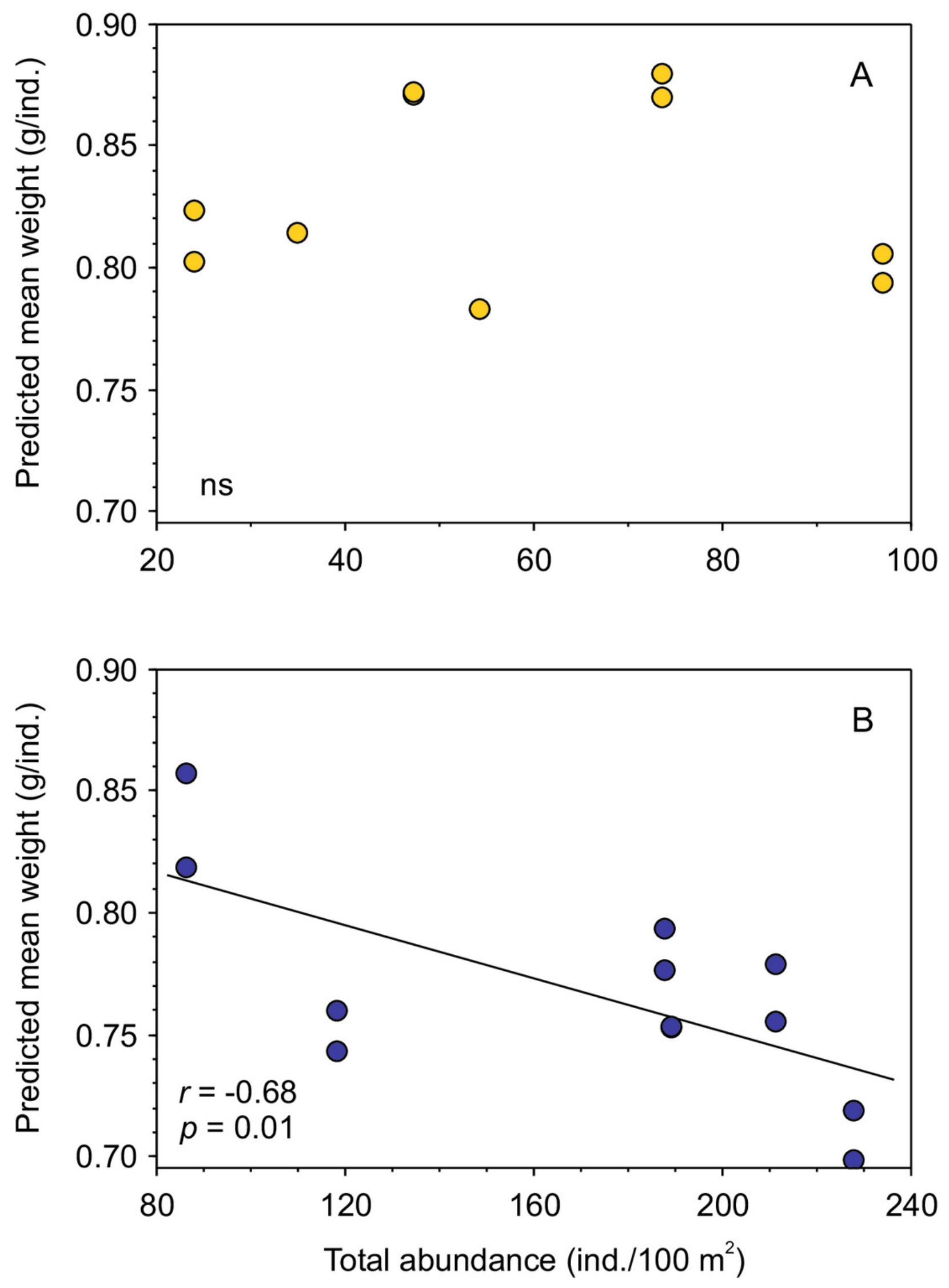

O Distant seagrass bed $\bigcirc$ Nearby seagrass bed 